\title{
Comportamento estrutural do Sistema Aquífero Guarani no estado de Goiás, Brasil
}

\author{
Luiz Antonio de Oliveira ${ }^{1 *}$, José Eloi Guimarães Campos ${ }^{2}$
}

\begin{abstract}
Resumo No estado de Goiás, Brasil, o Sistema Aquífero Guarani (SAG) é composto por arenitos eólicos de idade jurássica da Formação Botucatu que cobrem uma grande área de $44.000 \mathrm{~km}^{2}$, deste total, $35.138 \mathrm{~km}^{2}$ estão confinados pelos basaltos da Formação Serra Geral, enquanto os $9.580 \mathrm{~km}^{2}$ restantes representam as áreas de afloramentos. Com base nos dados de geologia de superfície e aqueles levantados em perfis de poços tubulares profundos foi possível estabelecer o comportamento estrutural do SAG, objetivo deste trabalho. As zonas de afloramentos estão distribuídas pelas regiões de Mineiros, Jatai e Aporé, com áreas de 8.832, 705 e $42 \mathrm{~km}^{2}$, respectivamente. O grau de confinamento do aquífero é controlado por duas estruturas geológicas: uma principal, aqui denominada de Depressão Tectônica Associada ao Lineamento do Rio Paranaíba (DTRP), de direção NE-SW e que condiciona o grau de confinamento na direção NW-SE e estruturas secundárias estão relacionadas aos lineamentos dos tributários do rio Paranaíba, de direção NW-SE, que condicionam o grau de confinamento na direção W-E. Os eventos tectônicos principais ocorreram no Jurássico, onde foram definidos os limites de deposição e de atitude das camadas areníticas e no Cretáceo durante o magmatismo da Formação Serra Geral, que promoveram a reativação dos planos de falhas do embasamento e a instalação de um rifte intracontinental, de direção NESW, cuja abrangência coincide com a DTRP (extensão nordeste do lineamento do rio Paraná). O magmatismo fissural que sucedeu a instalação do rifte seccionou localmente as camadas sedimentares pré-cretácicas.
\end{abstract}

Palavras-chave: Sistema Aquífero Guarani; comportamento estrutural; estado de Goiás; Brasil.

Abstract Structural behavior of the Guarani Aquifer System in Goiás state, Brazil. In Goiás state, Brazil, the Guarani Aquifer System (SAG) is composed of eolian sandstones of Jurassic age of the Botucatu Formation that cover a large area of $44,000 \mathrm{~km}^{2}$, of this total, 35,138 km² are confined by the basalts of Serra Geral Formation, while the $9,580 \mathrm{~km}^{2}$ remaining are outcrop areas. Based on data from surface geology and data from deep wells profiles was possible to establish the structural behavior of the SAG objective of this work. The outcrop areas are distributed to regions of Mineiros, Jatai and Aporé, with areas of 8,832, 705 and $42 \mathrm{~km}^{2}$ respectively. The degree of confinement of the aquifer is controlled by two geological structures: a main, here called Tectonics Depression Associated with Paranaíba Lineament (TDPL), of NE-SW direction and it conditions the degree of confinement in a NW-SE and secondary structures are guidelines related to the tributaries of the Paranaíba river of NW-SE direction, which determine the degree of confinement in the direction W/E. The main tectonic events occurred in the Jurassic, which defined the limits of deposition and attitude of the sandstone layers and Cretaceous, magmatism of the Serra Geral Formation, which promoted the reactivation of basement faults and the installation of an intracontinental rift of NE-SW direction, which coincides with the scope TDPL (northeastern extension of the Paraná River lineament). The fissural magmatism that followed the installation of the rift severed locally pre-cretaceous sedimentary layers.

Keywords: Guarani Aquifer System; Structural behavior; Goiás state; Brazil.

\section{INTRODUÇÃO Para Campos (1996), o} Aquífero Guarani engloba unidades geológicas confinadas, sotopostas aos basaltos, compostas por arenitos e lamitos, com aumento da proporção de argilas em direção à base do pacote sedimentar. Em termos gerais, aproximadamente $90 \%$ do conjunto está confinado e o restante ocupa áreas em faixas de afloramentos (Araújo et al. 1995). A porção confinada está sotoposta a espessos derrames basálticos correspondentes a Formação Serra Geral (Brasil), maior espessura de $1.723 \mathrm{~m}$ no estado de São Paulo (Galhano 2006), Formação Alto Paraná (Paraguai), maior espessura de 700 m (Consórcio Guarani 2006) e Formação Arapey (Uruguai), maior espessura de $1.023 \mathrm{~m}$ (Decoud \& Rocha 2000). A unidade hidroestratigráfica Guarani é composta por conjuntos de rochas com características relativamente homogêneas, de profundidade variável que abrange a quase totalidade da Bacia Sedimentar do Paraná (Zunino \& Ainchil 2000). A porção basal é constituída por arenitos de idade triássica: formações Pirambóia, Buena Vista e Grupo Rosário do Sul (Santa Ana 2004, Azevedo et al. 1985, Rosa Filho 2003, Giardin \& Faccini 2004, Araújo et al. 1995, 1999). A porção superior é constituída por pacote arenoso de idade jurássica: Formações Misiones (Palmieri et al. 1990),

\footnotetext{
${ }^{1}$ Instituto de Geografia, Universidade Federal de Uberlândia - UFU, Uberlândia (MG), Brasil. E-mail: luiz_ao@yahoo.com.br ${ }^{2}$ Instituto de Geociências, Universidade de Brasília - UnB, Brasília (DF), Brasil. E-mail: eloi@unb.br

*Autor correspondente
} 
Botucatu e Tacuarembó (Araújo et al. 1995, 1999, Rosa Filho 2003).

Em Goiás, o Sistema Aquífero Guarani (SAG) é representado pelos arenitos da Formação Botucatu, Oliveira (2009), que ocupam a quase totalidade da área de abrangência da Bacia Sedimentar do Paraná no estado. Em quase toda a sua extensão, o pacote arenítico encontra-se confinado entre unidades permianas (formações Corumbataí e Irati) e cretáceas (Formação Serra Geral e Grupo Bauru) (Gastmans 2007, Oliveira 2009).

\section{OBJETIVO E MÉTODOS O objetivo principal} deste trabalho foi descrever o comportamento estrutural do Sistema Aquífero Guarani no estado de Goiás, Brasil.

Para a caracterização do comportamento estrutural do Sistema Aquífero Guarani no estado de Goiás foram produzidas informações sobre a delimitação da área de ocorrência, espessura e estratigrafia do aquífero. A referida caracterização foi elaborada a partir de dados de superfície e informações levantadas em perfis de poços tubulares profundos localizados nas zonas confinada e aflorante, além de informações levantadas diretamente em campo nos aflorantentos das regiões de Santa Rita do Araguaia, Mineiros, Serranópolis, Jataí e Aporé.

Os trabalhos de detalhamento geológico, realizados ao longo dos anos de 2007 e 2008, constaram de levantamentos das cotas altimétricas e da localização geográfica de afloramentos e contatos geológicos. A localização geográfica e as cotas altimétricas dos afloramentos rochosos e dos poços tubulares profundos foram determinadas por receptor GPS da marca Garmin Etrex Legend, obtidos com acurácia de levantamento de $7 \mathrm{~m}$, configurado com Datum horizontal WGS84, Datum vertical de Imbituba, e leitura de posição em coordenadas geográficas.

As informações provenientes dos levantamentos geológicos e de perfis de poços foram tratadas no ArcGis Arcview, gerando mapas e perfis estratigráficos.

\section{CONTEXTO DO SISTEMA AQUÍFERO} GUARANI NO ESTADO DE GOIÁS No estado, o SAG está distribuído por uma área de $44.718 \mathrm{~km}^{2}$. A área de ocorrência compreende 3 zonas aflorantes, que juntas somam $9.580 \mathrm{~km}^{2}$ e a porção confinada com $35.138 \mathrm{~km}^{2}$ (Fig. 1).

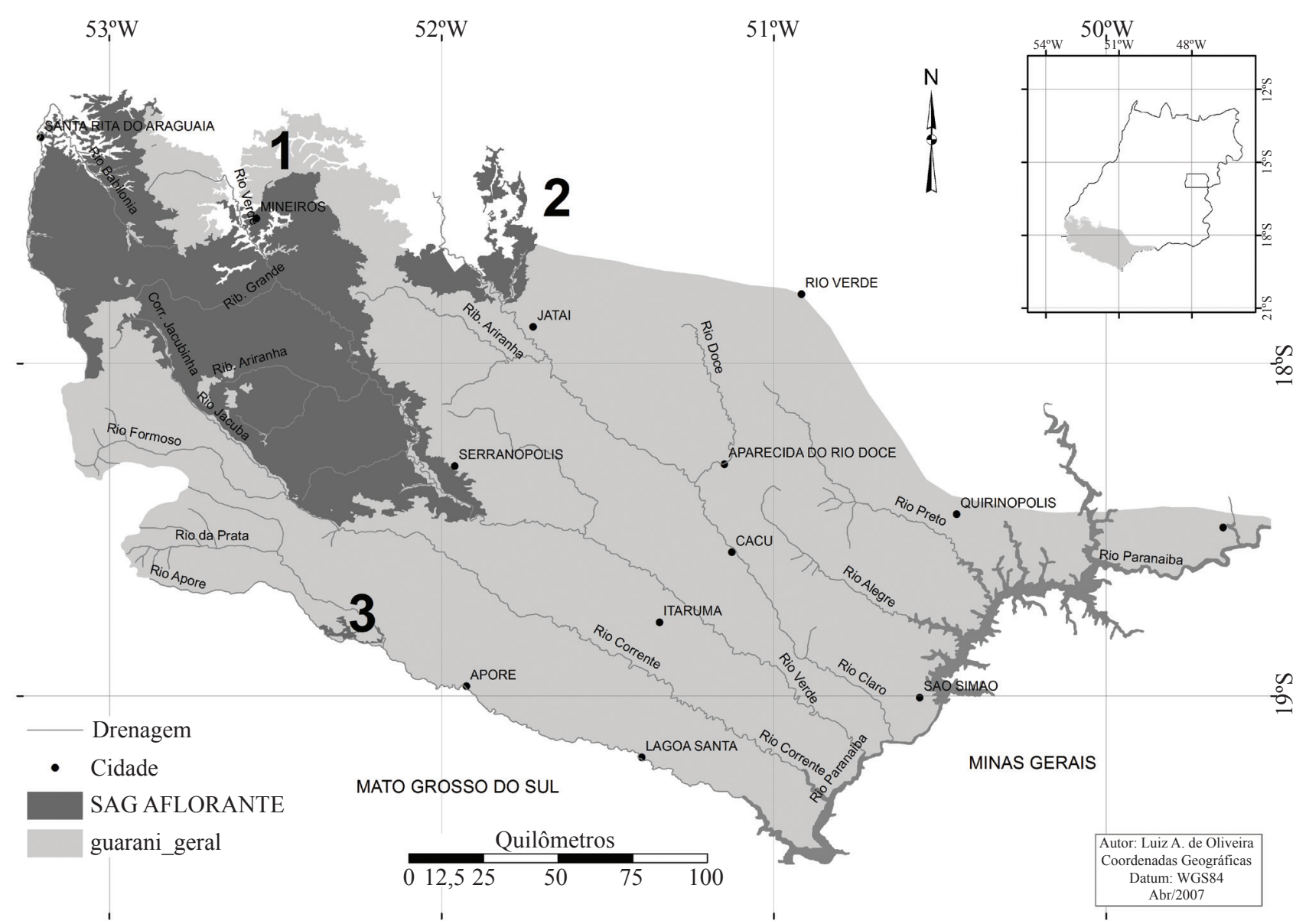

Figura 1 - Área de ocorrência do Sistema Aquifero Guarani em Goiás. Os afloramentos estão representados em polígonos escuros, indicados pelos números 1, 2 e 3, enquanto a porção confinada correspondente ao tom cinza claro. 
Zona aflorante A zona de afloramento mais representativa, com $8.832 \mathrm{~km}^{2}$, está localizada na região de Mineiros, que se estende desde o município de Santa Rita do Araguaia a noroeste, até o município de Serranópolis a sudeste, passando por Mineiros, indicada pelo número 1 no mapa apresentado na Fig. 1.

Esta região é drenada pelas bacias hidrográficas dos rios Araguaia, com fluxo superficial direcionado para noroeste, e Paranaíba, com fluxo superficial direcionado para sul e sudeste, em direção ao centro da Bacia Sedimentar do Paraná. O interflúvio que separa as duas bacias conforma uma linha divisória com altitudes superiores a $800 \mathrm{~m}$, sendo que o ponto mais alto chega a $930 \mathrm{~m}$. Essa região concentra a maior densidade de poços tubulares profundos perfurados no SAG no estado. Análise dos dados dos poços associada a informações de superfície indicam que as cotas altimétricas do topo e da base do pacote arenítico da Formação Botucatu no município de Santa Rita do Araguaia, limite noroeste do aquífero, são de 840 e 870 m respectivamente, com espessura de $30 \mathrm{~m}$. Na bacia do Rio Babilônia, município de Mineiros, as cotas são de $750 \mathrm{~m}$ para a base e de $840 \mathrm{~m}$ para o topo, com espessura de 90 metros. $\mathrm{Na}$ bacia do Rio das Pedras, município de Serranópolis, posicionada na porção sudeste da faixa de afloramentos, sentido centro da bacia sedimentar, as cotas de topo e base são de 480 e $740 \mathrm{~m}$ respectivamente, com espessura de $260 \mathrm{~m}$ (maior espessura da zona de afloramentos) (Figs. 2 e 3).

A segunda área mais expressiva de afloramentos, com área de $705 \mathrm{~km}^{2}$, localiza-se no município

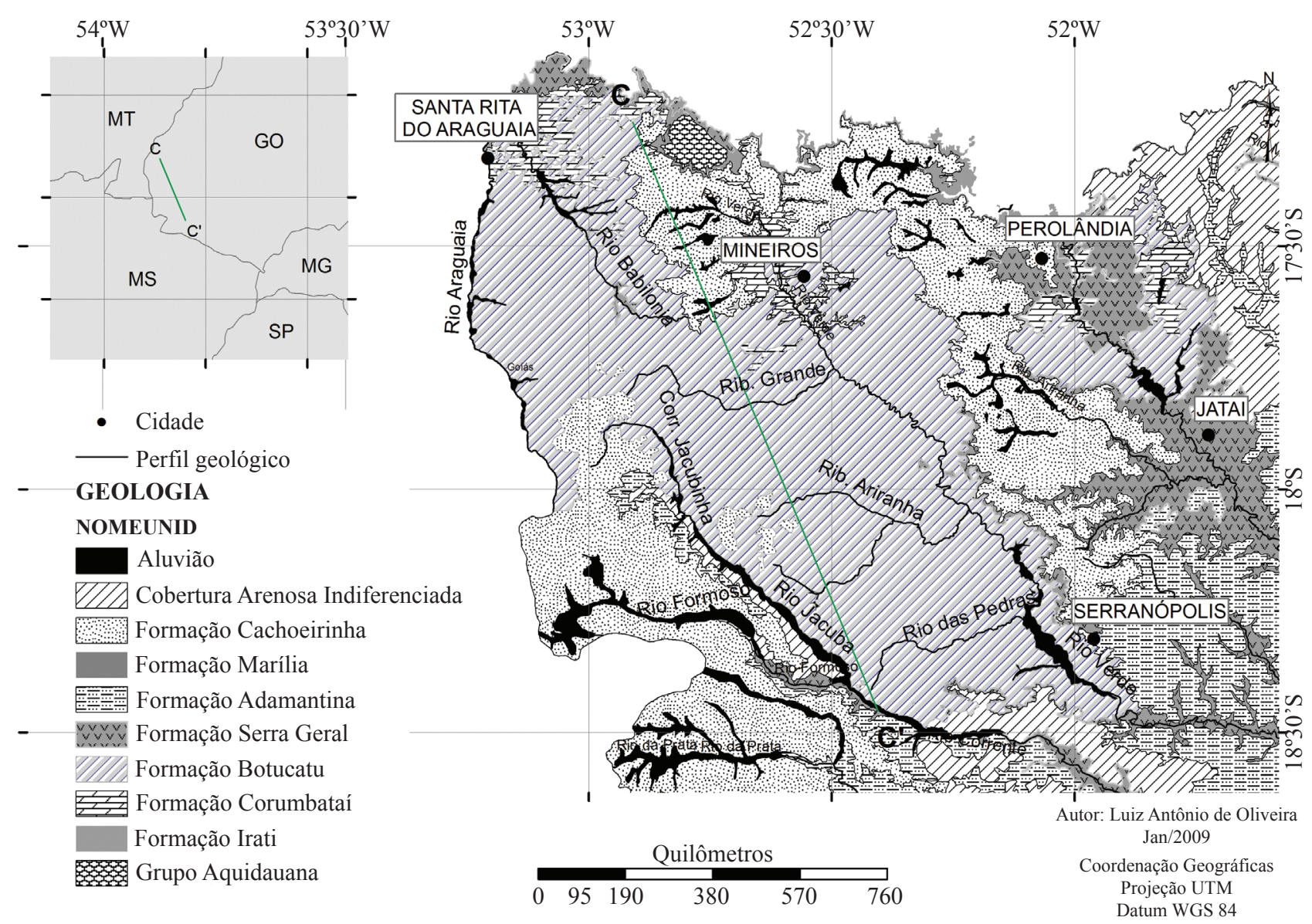

Figura 2 - Mapa e perfil geológico $C-C^{\prime}$, zona aflorante da região de Mineiros, englobando os municipios de Santa Rita do Araguaia, Mineiros e Serranópolis.

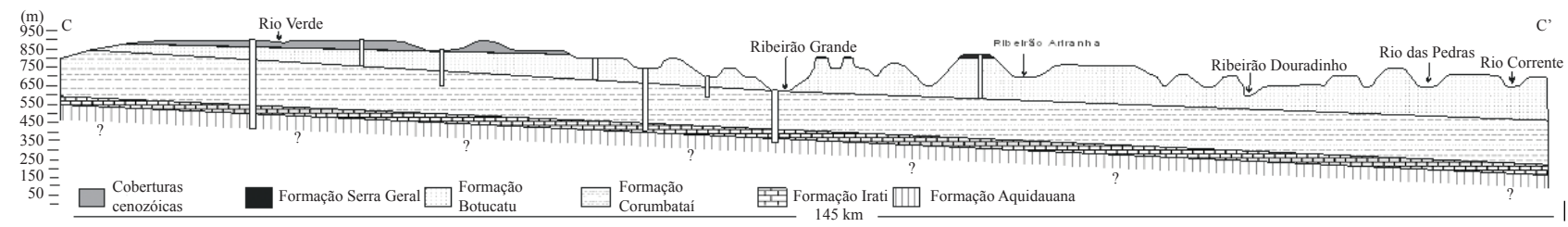

Figura 3 - Perfil estratigráfico $C-C$ ', zona aflorante da região de Mineiros, englobando os municípios de Santa Rita do Araguaia, Mineiros e Serranópolis. 
de Jataí, indicado pelo número 2 na Fig. 1. A área ocorre em forma de um "V", constituindo dois segmentos exumados pelas drenagens fluviais dos ribeirões Paraíso e das Torres, posicionados respectivamente à esquerda e à direita do Rio Claro.

$\mathrm{Na}$ Bacia do Ribeirão Paraíso, o afloramento conforma uma faixa alongada de direção NE-SW que se estende desde as cotas altimétricas de 660 até $900 \mathrm{~m}$, entre as nascentes do ribeirão Paraíso até sua confluência com o rio Claro. Nas porções mais altas, de acordo com a posição ocupada, os arenitos da Formação Botucatu estão em contato com as coberturas cenozoicas ou com os basaltos, enquanto que nos pontos mais baixos o contato inferior é com as rochas da Formação Corumbataí. Perfuração do poço da Petrobras na margem do ribeirão Paraíso, poço 2JA001GO, interceptou o topo do SAG na cota $550 \mathrm{~m}$, enquanto que em afloramentos, a maior cota superior está a $750 \mathrm{~m}$ de altitude, indicando uma espessura de $200 \mathrm{~m}$ para este local (Almeida 2003) (Figs. 4 e 5).

O segmento exumado pelo ribeirão das Torres é de direção NW-SE e se estende desde as cotas de $840 \mathrm{~m}$, nascente do córrego Formiguinha, até $660 \mathrm{~m}$ de altitude na confluência com o Rio Claro. Em grande parte desse segmento, o contato com os basaltos e com as rochas os sedimentos da Formação Corumbataí se dá por superfícies erodidas ou falhadas (Figs. 4 e 5). Esse conjunto de falhas tem atitude N60W e N30E, compondo pares. O contato tectônico da Formação Corumbataí com a Serra Geral pode ser evidenciado em certas porções da Serra do Caiapó, em que os folhelhos verdes da Formação Corumbataí ocorrem em cotas mais elevadas que os basaltos indicando que algumas destas falhas têm caráter rotacional em forma de falhas em tesoura. As superfícies que exumam estas falhas expõem com clareza o caráter tectônico destes contatos, a partir de sua linearidade e das cotas topográficas em que se situam.

No município de Aporé, o afloramento do SAG ocorre em forma de faixa estreita e alongada, exumada pelas drenagens dos rios Aporé e da Prata, totalizando uma área restrita de $42 \mathrm{~km}^{2}$, indicada pelo número 3 no mapa apresentado na Fig. 1 . O comportamento do afloramento em forma de ilha, resultante da erosão das camadas geológicas sobrepostas e o gradiente topográfico negativo de $140 \mathrm{~m}$ em relação à zona aflorante de Serranópolis, permitem inferir que essa região se caracteriza como uma zona de alívio de pressão de confinamento do aquífero, comportando-se como exutório.

\section{Zona confinada}

A caracterização da porção confinada do SAG foi elaborada com base em informações levantadas a partir de perfis de poços tubulares profundos. De acordo com o grau de confinamento, o aquífero foi subdivido em zonas de baixo, médio e alto confinamento. Na definição dos distintos graus de confinamento seguiu-se o dimensionamento proposto por Rosa Filho (2004), no qual, as zonas de baixo confinamento, onde a profundidade do topo do pacote arenítico é de até $200 \mathrm{~m}$; as zonas de médio confinamento, cuja profundidade do topo situa-se entre 200 e $500 \mathrm{~m}$ e por fim, as zonas de alto grau de confinamento onde a profundidade do topo do aquífero é superior a $500 \mathrm{~m}$.

O grau de confinamento do aquífero é controlado por duas estruturas: uma principal, aqui denominada de Depressão Tectônica Associada ao Lineamento do Rio Paranaíba (DTRP), de direção NE-SW e que condiciona o grau de confinamento na direção NW-SE. De acordo com a posição ocupada em relação a essa estrutura, o aquífero foi subdividido em porções confinadas oeste e leste. Estruturas secundárias estão relacionadas aos lineamentos dos tributários do rio Paranaíba, de direção NW-SE, que condicionam o grau de confinamento do aquífero na direção W-E (Fig. 6).

ZONA DE ALTO GRAU DE CONFINAMENTO RELACIONADA À DEPRESSÃO TECTONNICA ASSOCIADA AO LINEAMENTO DO RIO PARANAÍBA

É a principal estrutura geológica que exerce controle no comportamento do SAG no estado de Goiás. Análise de dados de campo de perfil de poços indica que a estrutura de direção NE-SW condiciona, regionalmente, o grau de confinamento na direção NW-SE. Em toda a porção posicionada a oeste da depressão, o grau de confinamento aumenta segundo direção NW$\mathrm{SE}$, enquanto que do lado leste o grau de confinamento é em direção oposta. Perfuração de poço tubular profundo na Usina São Francisco, município de Quirinópolis, atravessou $16 \mathrm{~m}$ de arenito e interceptou o topo do aquífero a $838 \mathrm{~m}$ de profundidade (Figs. 7 e 8). Na Usina Boa Vista, distante a $23 \mathrm{~km}$ da Usina São Francisco, na direção SW, sentido centro da bacia sedimentar, perfuração de poço tubular profundo interceptou o topo do aquífero a $926 \mathrm{~m}$ de profundidade (Figs. 7 e 8 ).

A porção confinada posicionada a oeste da DTRP engloba $90 \%$ da área de ocorrência do SAG no estado de Goiás, podendo ser subdividida em 


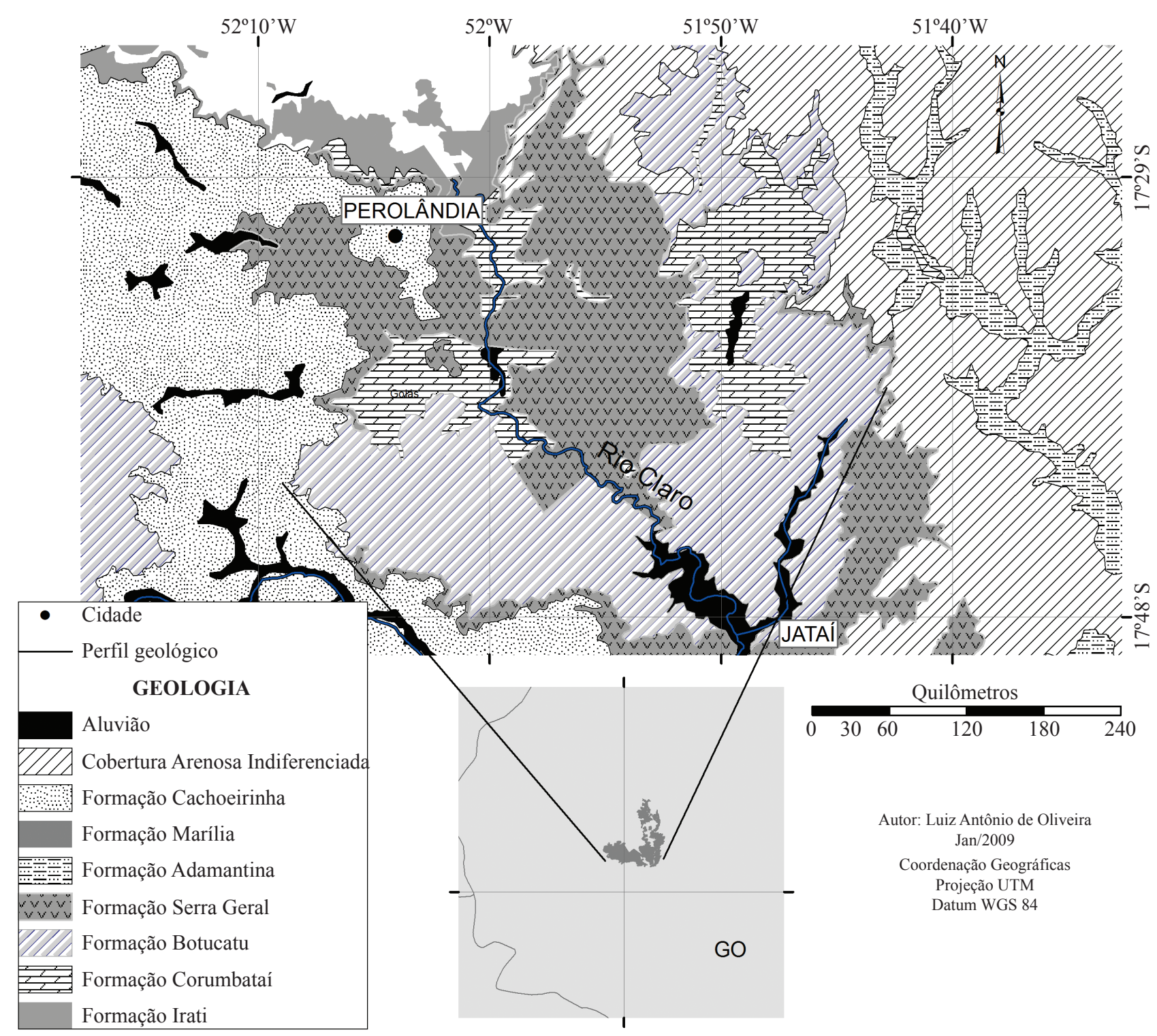

Figura 4-Mapa geológico da região de Jataí.

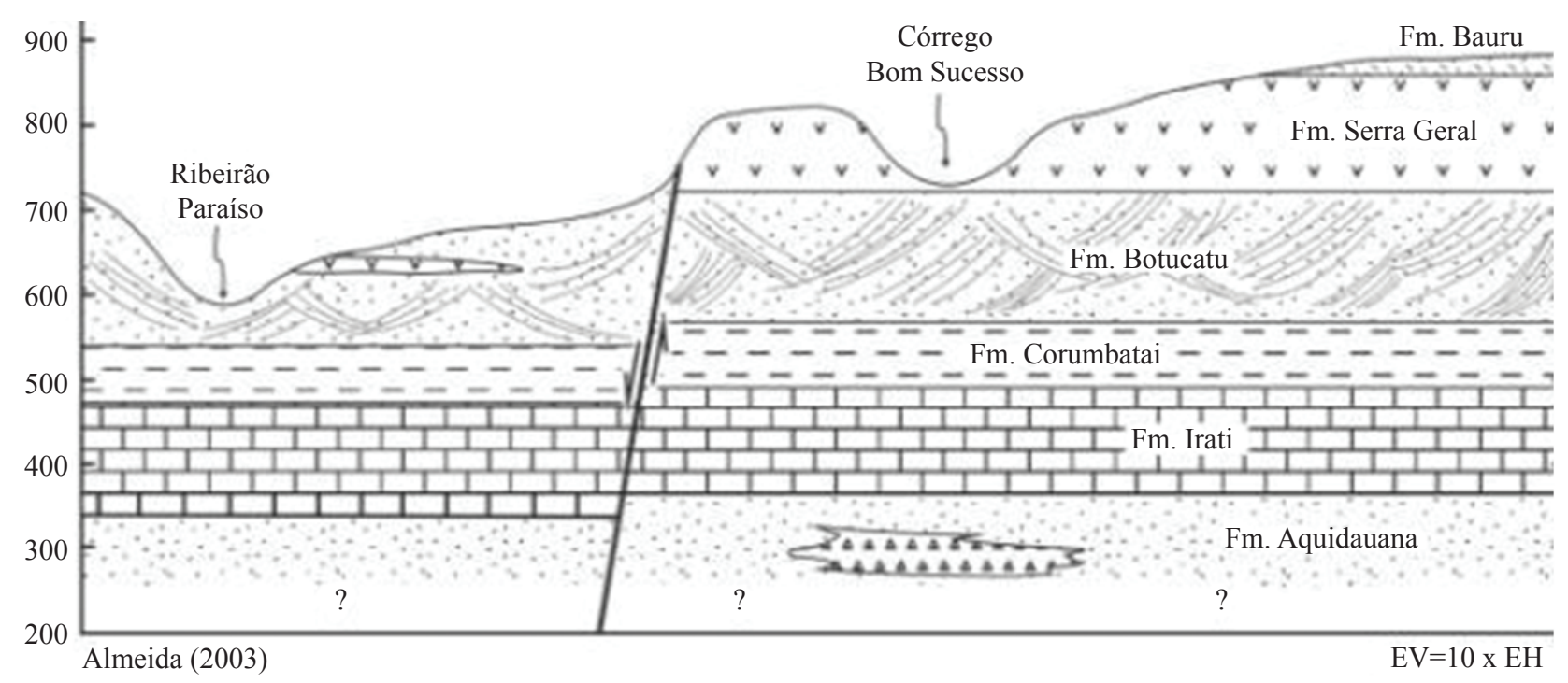

Figura 5 - Perfil estratigráfico da região de Jataí. 


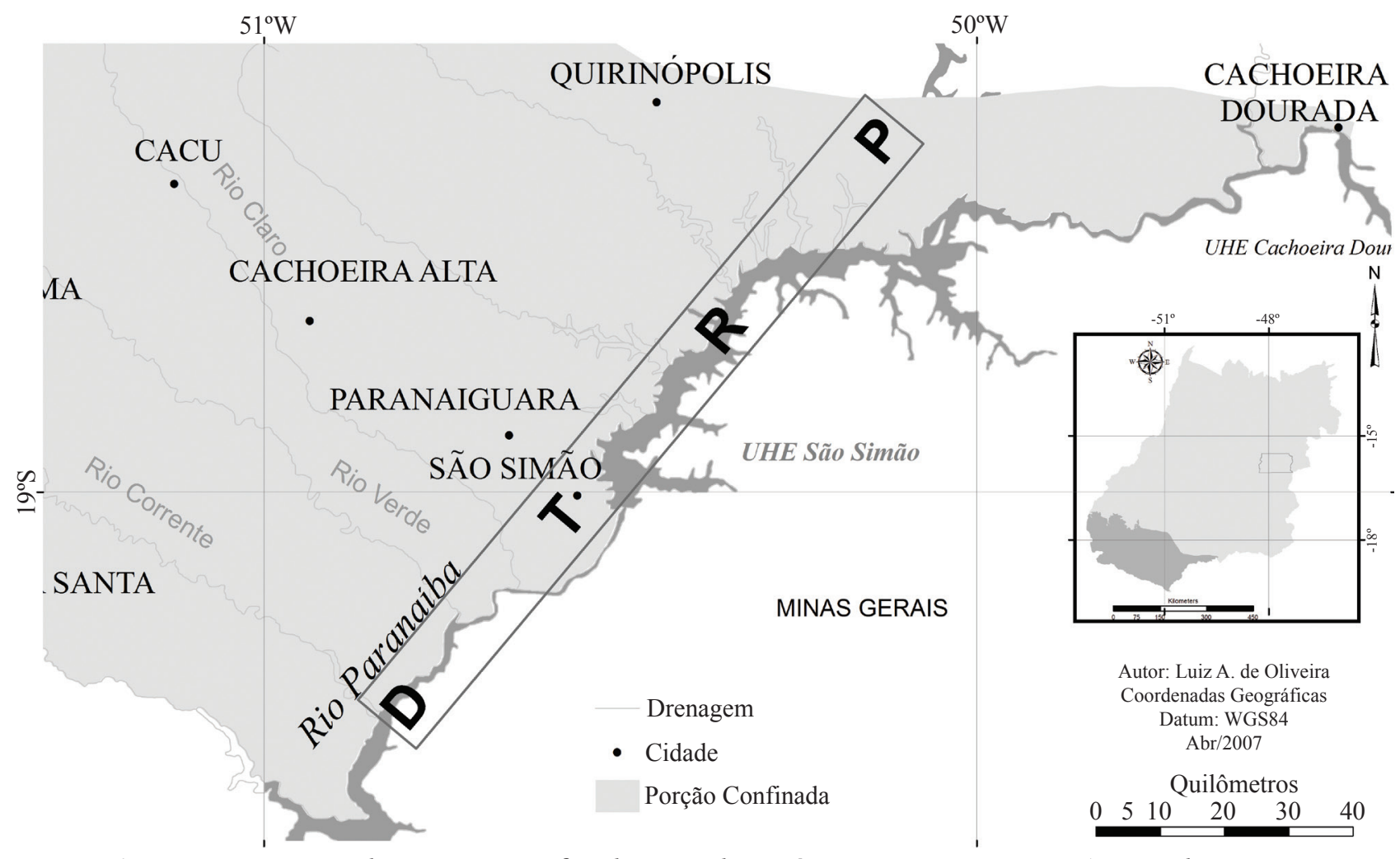

Figura 6-Posicionamento das porções confinadas em relação à Depressão Tectônica Associada ao Lineamento do Rio Paranaiba e principais estruturas de controle.

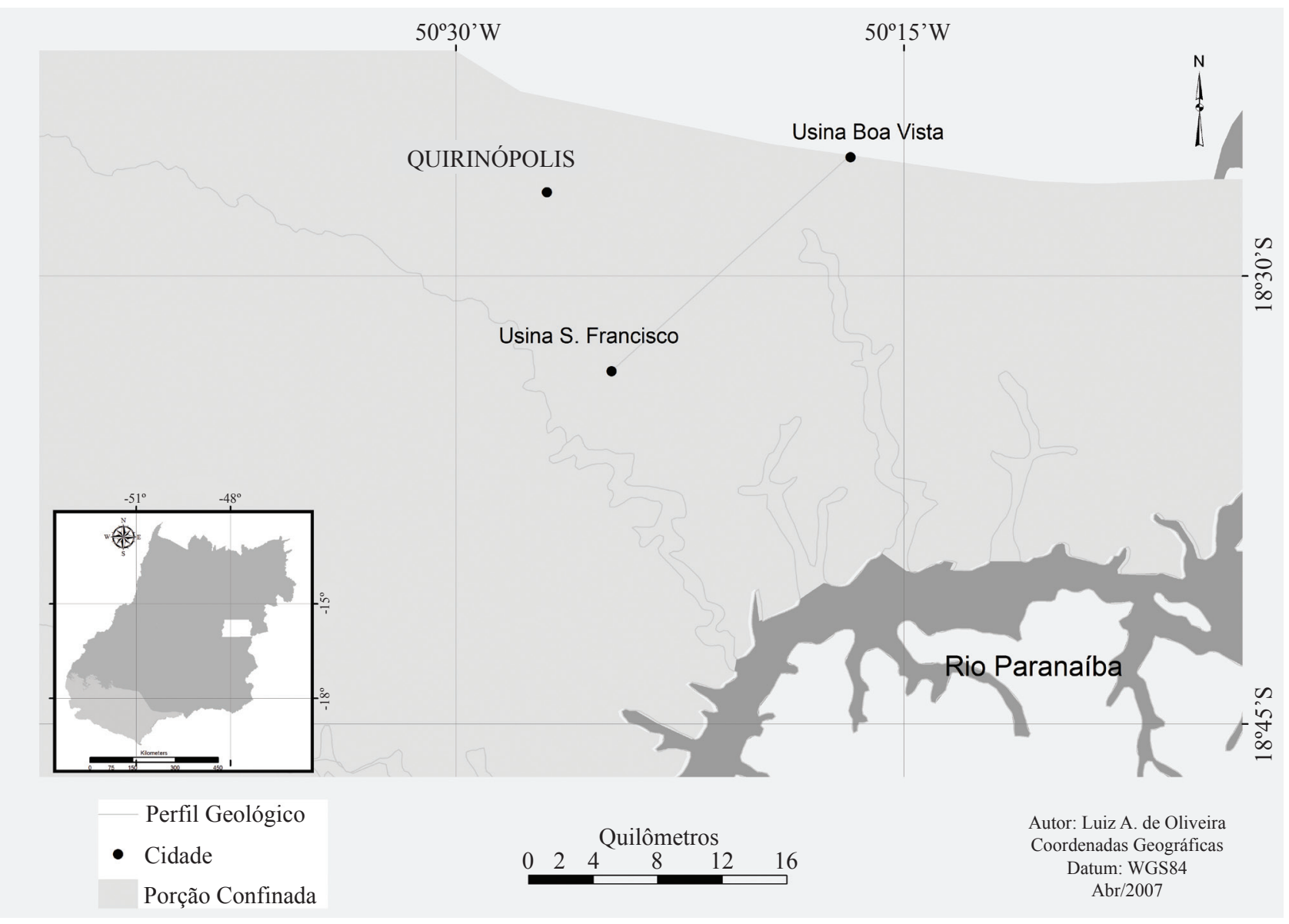

Figura 7 - Mapa e perfil geológico entre as Usinas São Francisco e Boa Vista, região de Quirinópolis. 
duas zonas de acordo com o grau de confinamento: a) Zona de baixo grau de confinamento que se estende desde os limites com os afloramentos das regiões de Serranópolis, a noroeste, e Jataí, a norte, até o lineamento do rio Claro, onde a profundidade máxima do topo do pacote arenítico não ultrapassa $400 \mathrm{~m}$; b) Zona de médio grau de confinamento posicionada entre o lineamento do rio Claro até a DTRP. Nesta zona a profundidade do topo do pacote arenítico varia entre 200 e 500 m (Figs. 9 e 10). Perfurações de poços tubulares profundos nas áreas vizinhas a Lagoa Santa e Itajá atravessam os derrames basálticos e interceptam o topo do SAG a $140 \mathrm{~m}$ de profundidade (Figs. 9 e 10). Essa região ocupa posição mais interior na bacia sedimentar, distante $150 \mathrm{~km}$ ao sul dos afloramentos de Jataí e $95 \mathrm{~km}$ a sudeste dos afloramentos de Serranópolis. Devido à distância das áreas de afloramento e o posicionamento na bacia sedimentar, acreditava-se num maior mergulho dos pacotes areníticos da Formação Botucatu, acompanhado de aumento do confinamento do aquífero nessa região. Análise integrada dos dados de perfis de poços profundos e posicionamento em relação à área de afloramento no município de Aporé permitiu a

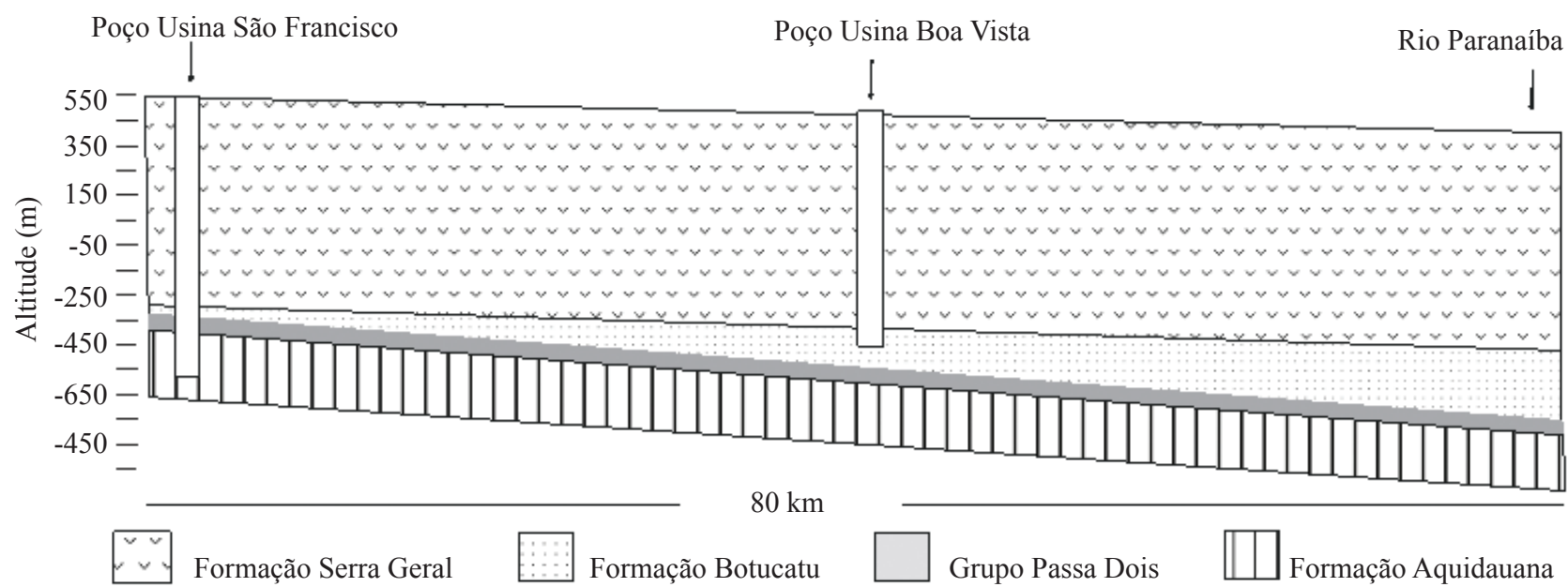

Figura 8-Perfil estratigráfico entre as Usinas São Francisco e Boa Vista - região de Quirinópolis.

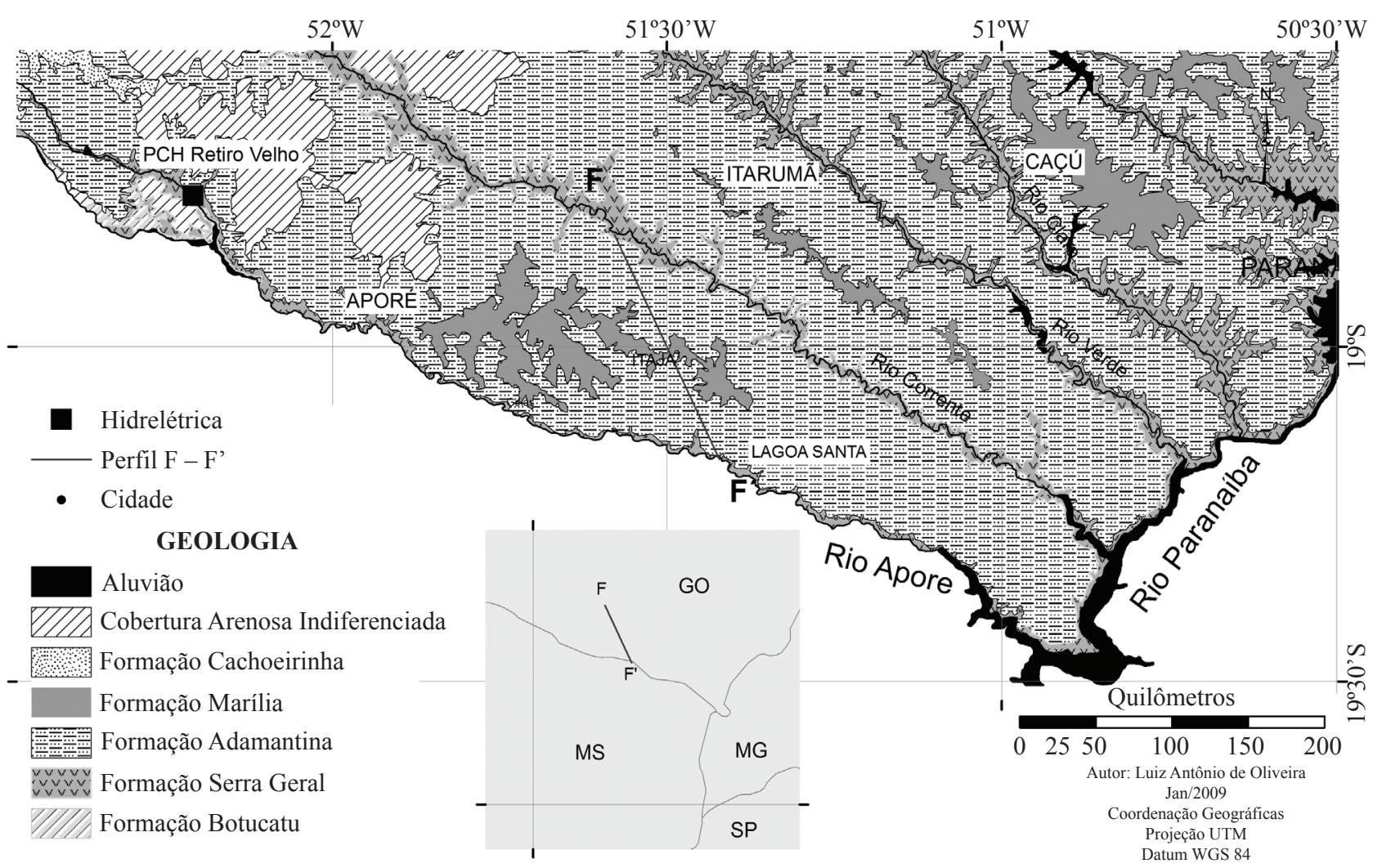

Figura 9-Mapa e perfil geológico $F-F^{\prime}$, porção posicionada a oeste da Depressão Tectônica Associada ao Lineamento do Rio Paranaíba. 
compreensão do comportamento estrutural do aquífero nesse setor. Poço perfurado na $\mathrm{PCH}$ Retiro Velho, posicionada no rio da Prata próximo a confluência com o rio Aporé, atravessou os derrames basálticos e interceptou o topo do aquífero a $40 \mathrm{~m}$ de profundidade (Fig. 9).

No município de Caçú, foram perfurados 12 poços que interceptaram o aquífero em profundidades variando de 286 a $430 \mathrm{~m}$.

A porção confinada posicionada a leste da DTRP compreende uma faixa estreita e alongada na direção W-E, que se estende desde a zona de contato do aquífero com o embasamento cristalino entre os municípios de Itumbiara e Cachoeira Dourada a leste, até a DTRP a oeste. Nessa região, o aquífero é medianamente confinado, onde as profundidades de topo do pacote arenítico encontram-se entre 300 e 500 m (Figs. 11 e 12).

ESTRUTURAL Regionalmente, a estrutura do aquífero no estado é condicionada pela DTRP (extensão nordeste do lineamento do rio Paraná), de direção SW-NE, depocentro dos basaltos da Formação Serra Geral, cuja espessura alcança mais de $900 \mathrm{~m}$.

Como mencionado anteriormente, as informações sobre o detalhamento da DTRP foram levantadas em acompanhamento de perfurações de poços no município de Quirinópolis. Na Usina São Francisco, a perfuração do Poço 2 interceptou o topo do SAG a $824 \mathrm{~m}$ de profundidade, tendo atravessado $16 \mathrm{~m}$ do pacote arenítico, seguidos por $40 \mathrm{~m}$ de litotipos do Grupo Passa Dois e mais $340 \mathrm{~m}$ dos litotipos da Formação Aquidauana. A cota de superfície do referido poço está a $540 \mathrm{~m}$ de altitude. No poço na Usina Boa Vista, o topo do pacote arenítico está a 932 $\mathrm{m}$ de profundidade, onde a espessura interceptada do aquífero é de $85 \mathrm{~m}$, não tendo sido atravessado pela perfuração. A cota de superfície do poço está a $490 \mathrm{~m}$ de altitude. Em apenas $23 \mathrm{~km}$ de distância entre as duas usinas a espessura do aquífero passa de 15 para mais de $85 \mathrm{~m}$, considerando apenas a espessura do arenito interceptada no segundo poço. O gradiente do topo do pacote arenítico é de $40 \mathrm{~m}$ em direção ao centro da Bacia Sedimentar.

Observa-se no mapa de drenagens que o rio Paranaíba constitui a extensão nordeste do lineamento do rio Paraná. Na divisa entre os estados de Goiás e Minas Gerais, desde a confluência com o rio Grande, o traçado do rio Paranaíba segue uma linha reta até a região onde recebe as águas dos rios Preto e São Francisco, seus afluentes da margem direita, a partir daí, o traçado sofre uma inflexão de $30^{\circ} \mathrm{E}$. Apesar de em superfície existir esta inflexão da linha da drenagem, em subsuperfície, a estrutura segue em linha reta, direção NE para o interior do estado de Goiás, sendo coincidente com a depressão tectônica que representa a zona de maior confinamento do aquífero.

O detalhe do comportamento do aquífero pode ser observado nos dois mapas geológicos e em seus respectivos perfis estratigráficos, de direção norte-sul (Figs. 13 e 14) e leste-oeste (Figs. 15 e 16).

$\mathrm{O}$ mapa potenciométrico evidencia gradiente topográfico de $1.650 \mathrm{~m}$ entre as áreas mais elevadas, posicionadas a $900 \mathrm{~m}$ e $880 \mathrm{~m}$ de altitude nas zonas de afloramentos da região de Jataí e Mineiros, e áreas mais rebaixadas dispostas em cotas negativas de $750 \mathrm{~m}$ na DTRP, no extremo sul do estado de Goiás (Fig. 17).

Análise do mapa de isópacas do Sistema Aquífero Guarani no estado (Fig. 18) evidencia aumento de espessura a partir dos limites das zonas aflorantes da região de Mineiros a noroeste e Jataí a

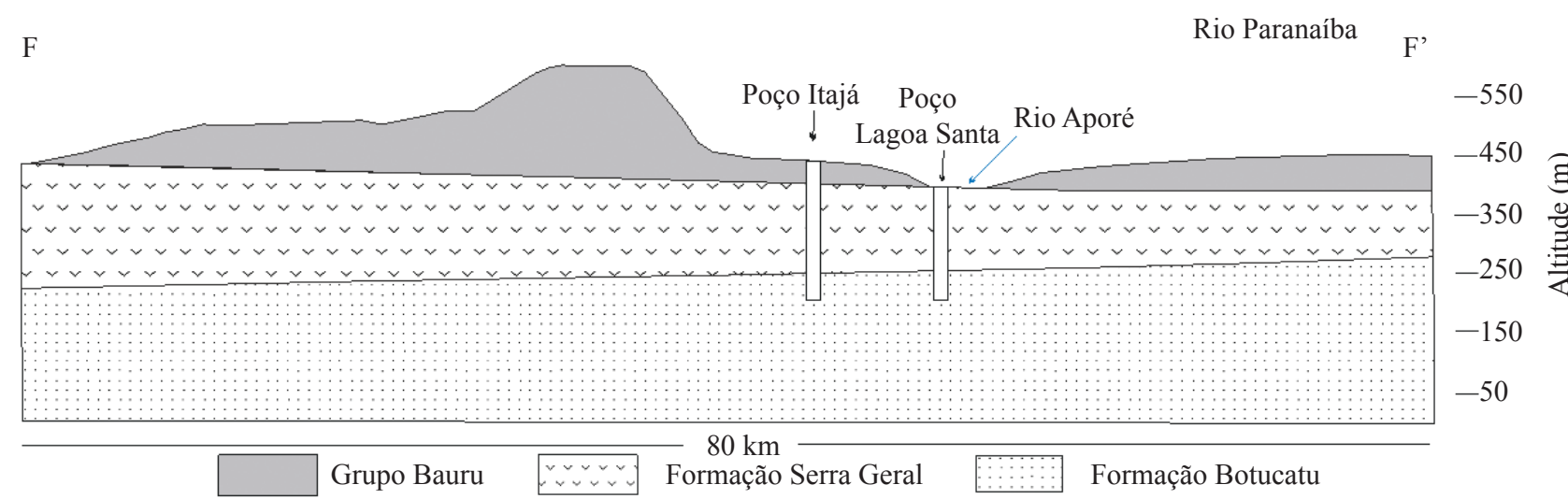

Figura 10 - Perfil estratigráfico $F-F^{\prime}$, da porção posicionada a oeste da Depressão Tectônica Associada ao Lineamento do Rio Paranaiba. 
norte e dos contornos da porção confinada limitados pela borda da bacia a nordeste e leste.

No limite noroeste do aquífero, zona aflorante da região de Mineiros, divisa dos municípios de Mineiros e Santa Rita do Araguaia, a espessura dos arenitos é de $30 \mathrm{~m}$, evoluindo para $260 \mathrm{~m}$ no limite oposto da zona aflorante, município de Serranópolis. $\mathrm{Na}$ zona aflorante de Jataí a norte, o aquífero segue o mesmo comportamento da região de Mineiros, ou seja, há aumento de espessura do pacote arenítico em direção ao centro da Bacia Sedimentar. Nessa região, no local onde os arenitos mergulham sob as vulcânicas da Formação Serra Geral, às margens do Ribeirão Paraíso, a espessura do arenito é de $200 \mathrm{~m}$.

Na região de Cachoeira Dourada, posicionada no limite leste do aquífero, a espessura aproximada dos arenitos é de $150 \mathrm{~m}$.

No poço, código 2RA0001MS, perfurado pela Petrobras na cidade de Cassilândia (MS), posicionada na divisa com o estado de Goiás, a espessura interceptada do pacote arenítico é de $550 \mathrm{~m}$.

Análise integrada dos dados indica aumento da espessura do aquífero, no estado, nas direções sul e sudeste, regiões de Lagoa Santa e de São Simão,

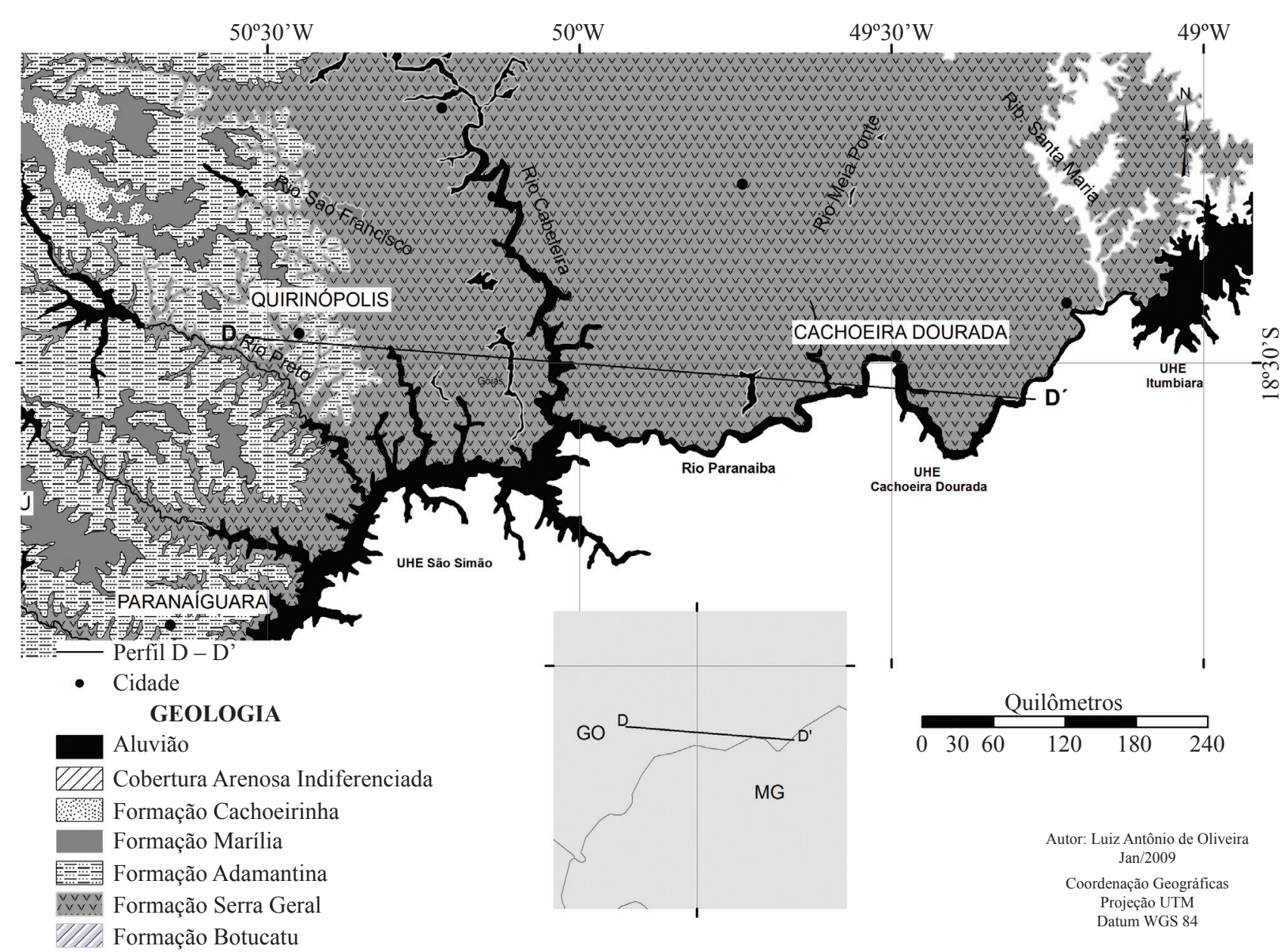

Figura 11 - Mapa e perfil geológico D - D', porção posicionada a leste da Depressão Tectônica Associada ao Lineamento do Rio Paranaíba.

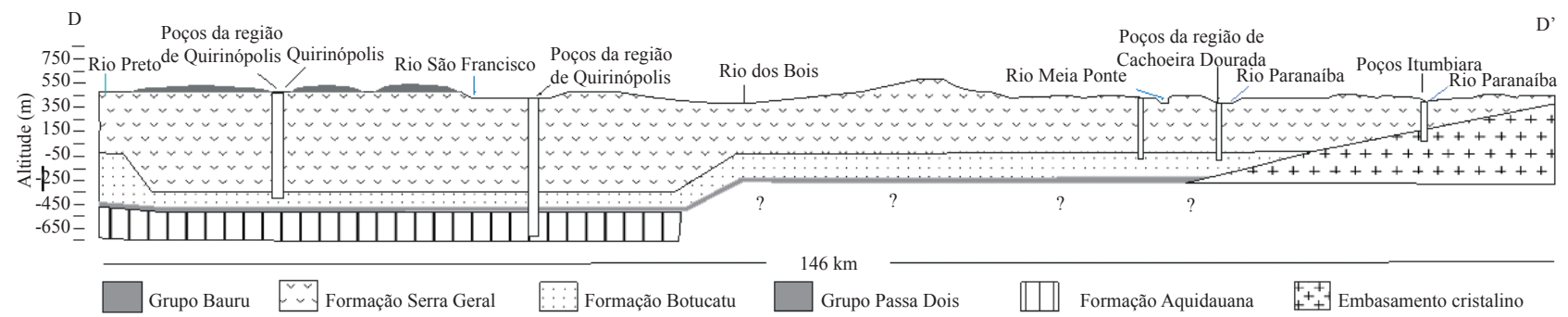

Figura 12 - Perfil estratigráfico D-D', com destaque para a posição dos poços das regiões de Quirinópolis, Cachoeira Dourada e Itumbiara. 
respectivamente, (Fig. 18), sendo que a maior espessura é de $550 \mathrm{~m}$, porção sul.

Limites A partir de dados de poços e de toda a discussão do item sobre a geometria do aquífero, foi possível refinar os limites do SAG em Goiás. Os limites das zonas aflorantes foram confirmados como sendo os mesmos constantes na base cartográfica da Agência Nacional de Energia Elétrica (ANEEL) (ANNEL 2000).

Os dados dos perfis de poços da cidade de Rio Verde e o acompanhamento da perfuração dos poços

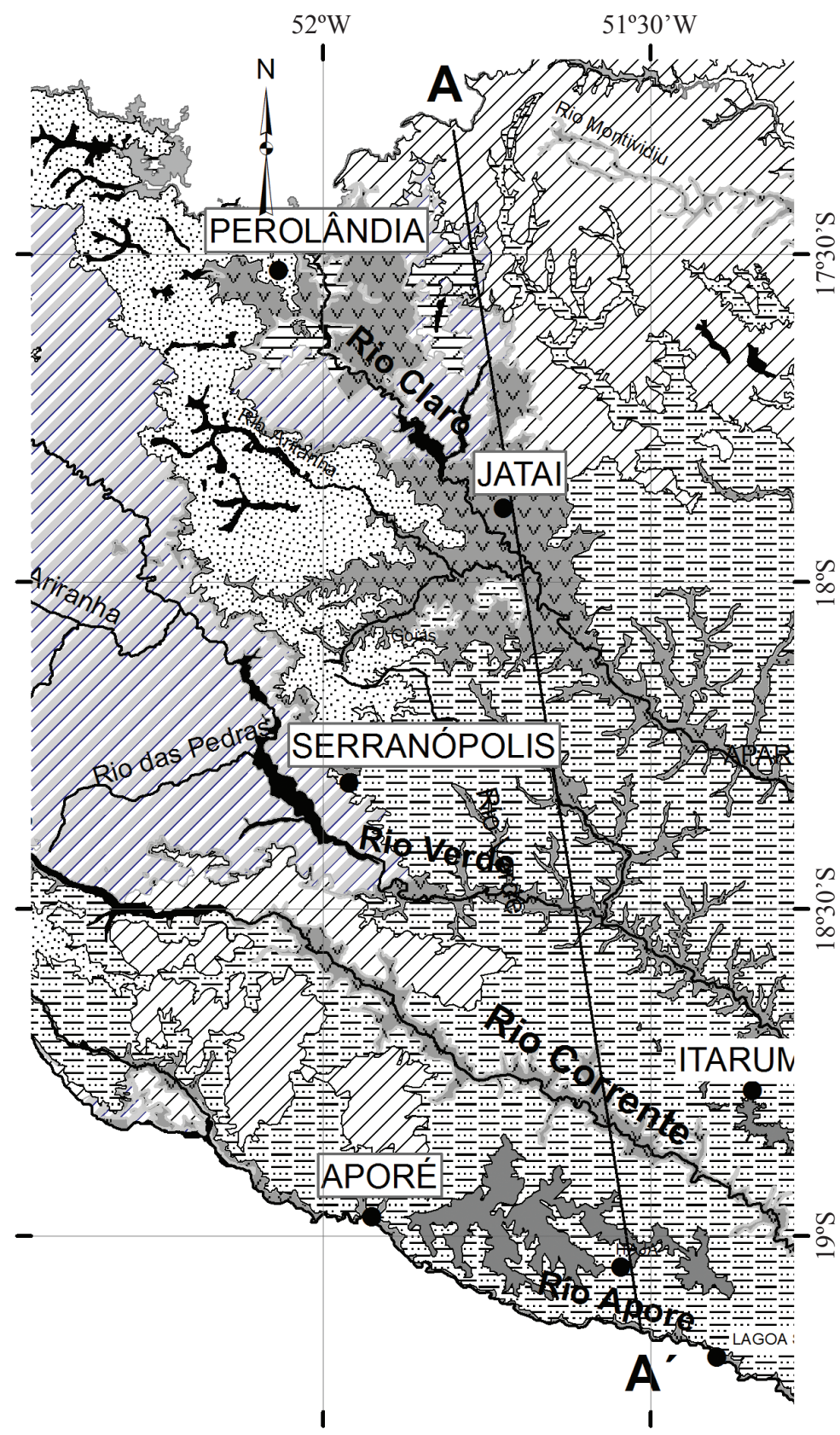

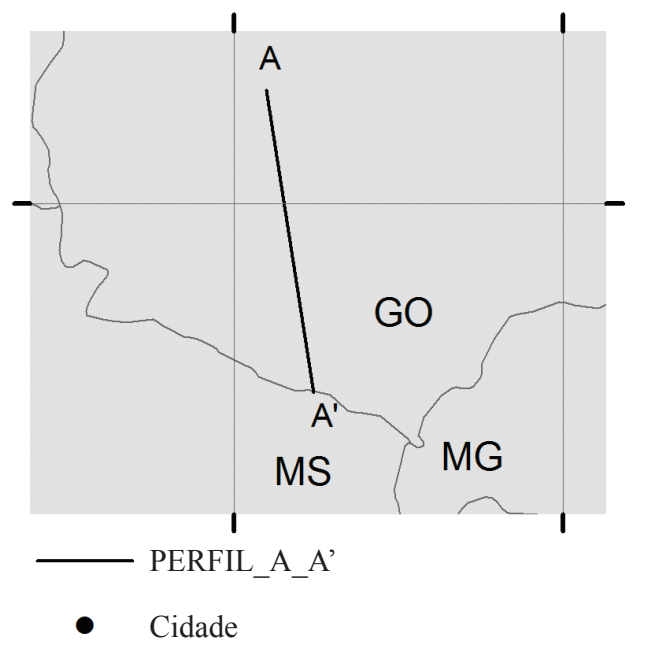

GEOLOGIA
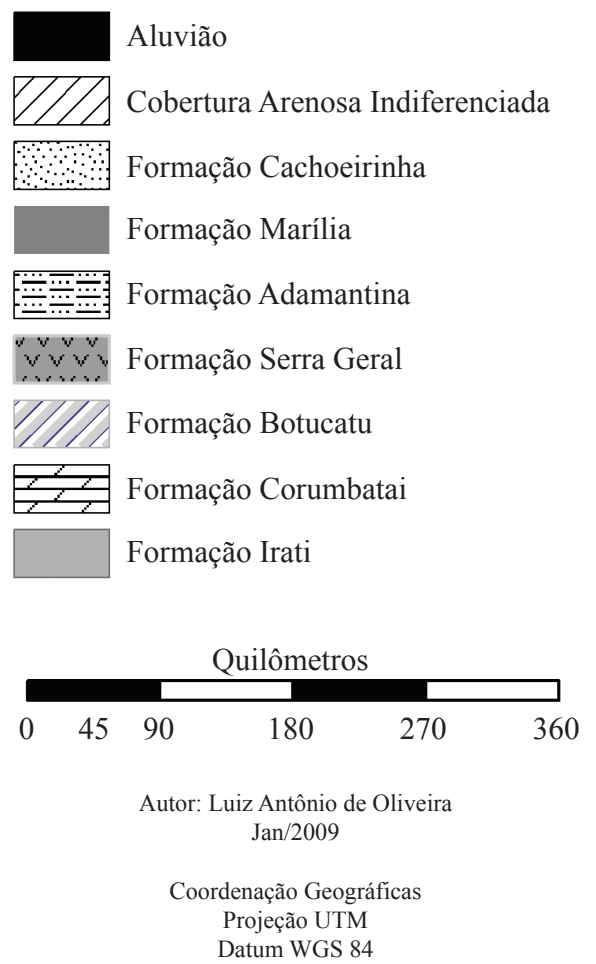

Figura 13 - Mapa e perfil geológico A-A', corta a região de estudos de norte a sul.

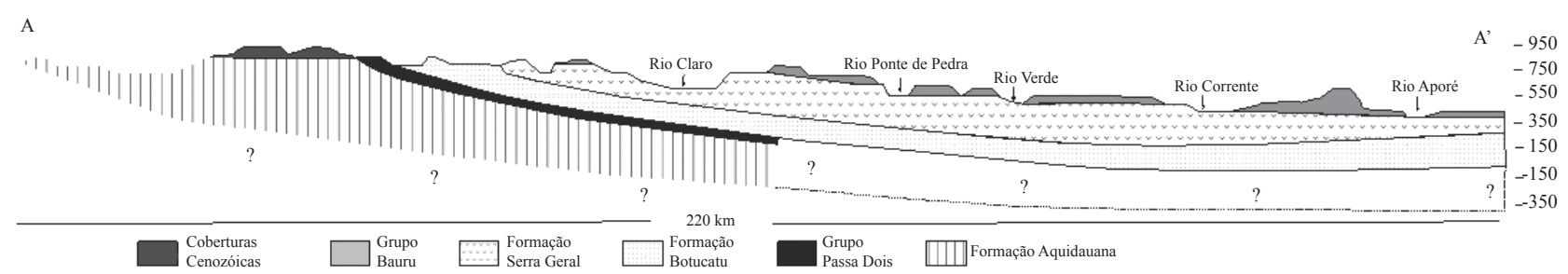

Figura 14 - Perfil estratigráfico $A-A$ '. 
das cidades de Quirinópolis e Cachoeira Dourada permitiram a redefinição dos limites da zona confinada.

Depois de refinados os novos limites, constatou-se uma retração da área de ocorrência em relação aos limites sugeridos por França et al. (1994) e utilizados por outros autores, que supunham que toda a porção confinada do aquífero, nesta região, coincidia com a extensão de ocorrência dos basaltos. A área atualizada passou de $73.008 \mathrm{~km}^{2}$, limite antigo, para $44.718 \mathrm{~km}^{2}$, limite atual.

Tectônica No Jurássico, os contornos do embasamento na região entre Quirinópolis e Itumbiara não eram muito diferentes dos atuais. A poligonal entre os dois municípios constituía um alto de embasamento que limitava ao norte o avanço dos ciclos de sedimentação da Bacia do Paraná. De modo contrário, toda a região posicionada a oeste desta área estava situada em cotas altimétricas inferiores o que permitiu a continuidade da sedimentação em direção noroeste, se estendendo até o interior do estado do Mato Grosso.
O evento tectônico principal é relacionado ao magmatismo da Formação Serra Geral durante o Cretáceo. Nesse período os processos de estiramento crustal que conduziram ao rompimento do Gondwana, promoveram na região a reativação dos planos de falhas do embasamento. O estiramento promoveu a instalação de um rifte intracontinental, de direção NE-SW, cuja abrangência coincide com a DTRP, que é a extensão nordeste do lineamento do rio Paraná. O magmatismo fissural que sucedeu a instalação do rifte seccionou localmente as camadas sedimentares pré-mesozoicas. Próximo ao segmento do rifte, os derrames basálticos alcançam mais de $900 \mathrm{~m}$ de espessura, adelgaçando para noroeste e sudeste à medida que se distancia da falha principal. O ponto exato da linha do rifte não pode ser definido, sendo sua posição estimada pelo comportamento da espessura dos derrames nos perfis de poços. Outro fator que corrobora essa proposta é a diferenciação hidroquímica e o grande contraste das idades de circulação
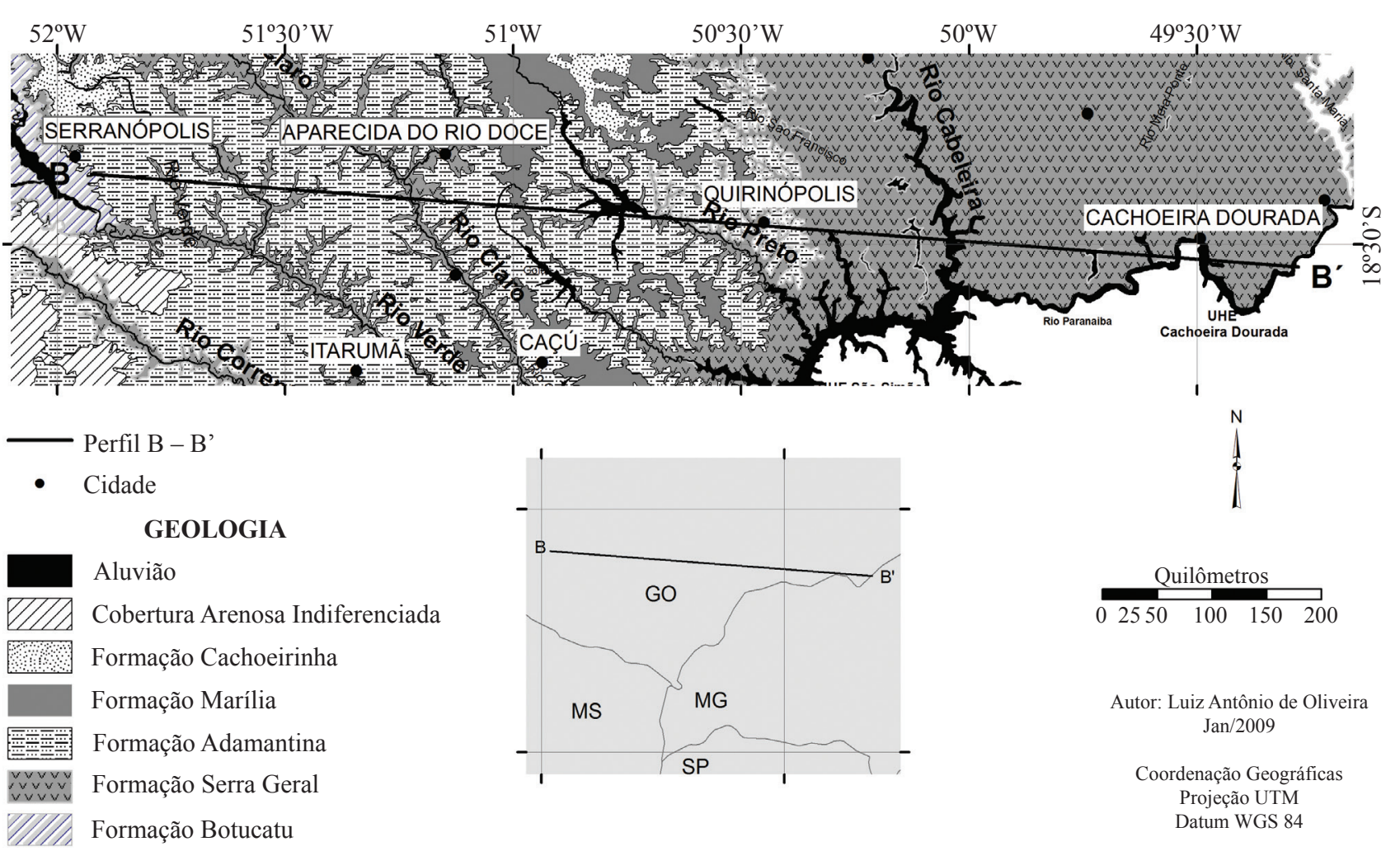

Figura 15 - Mapa e perfil geológico B-B', corta a região de estudos de leste a oeste.

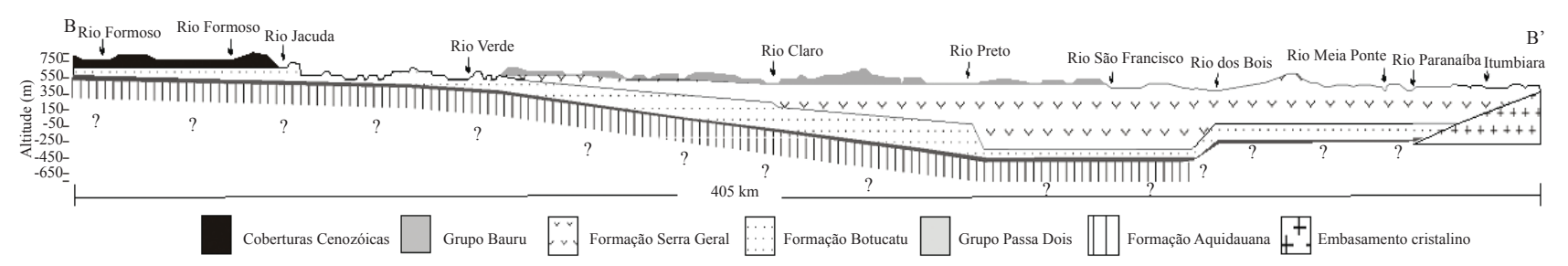

Figura 16 - Perfil estratigráfico $B-B^{\prime}$. 


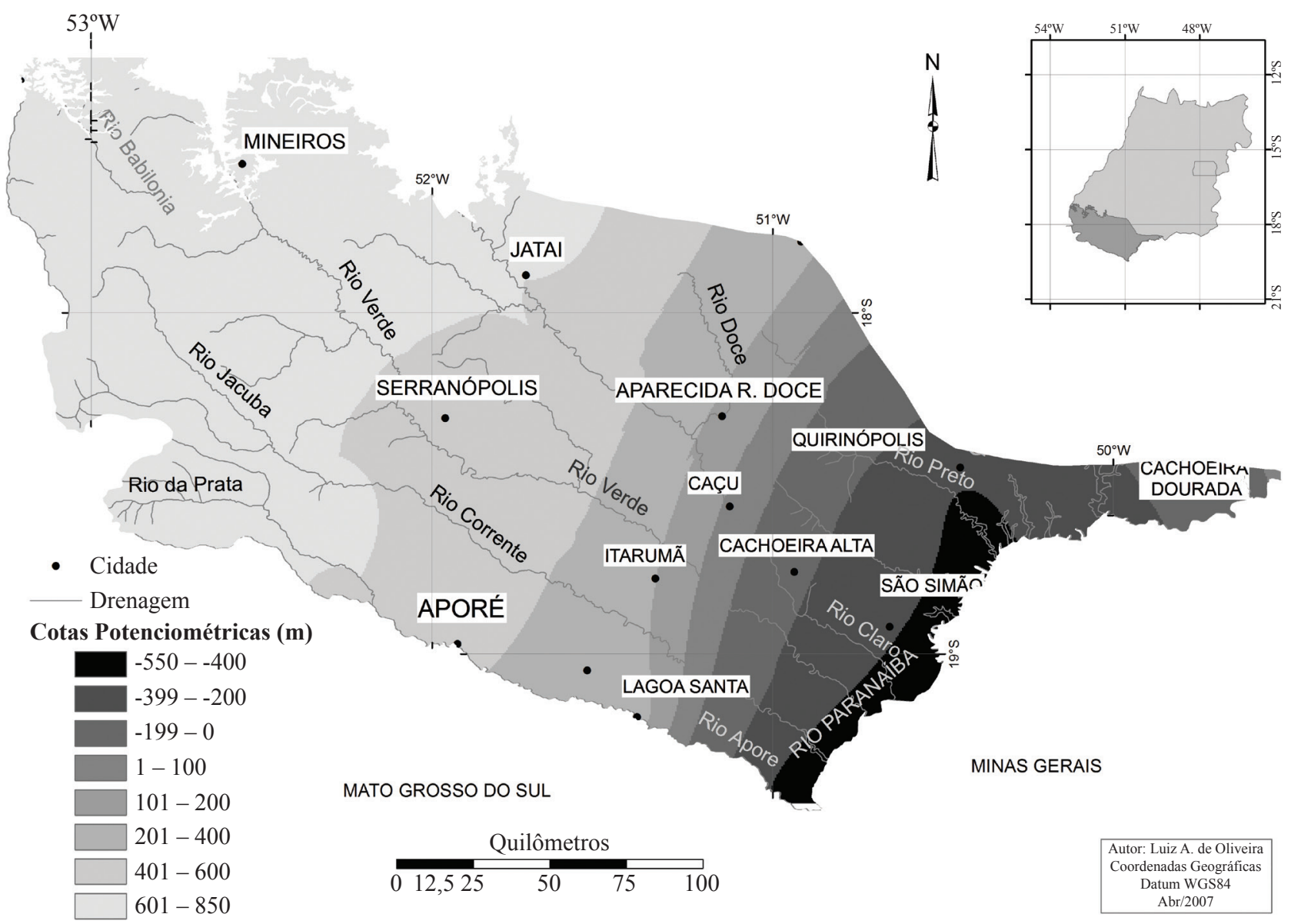

Figura 17 - Mapa potenciométrico do Sistema Aquífero Guarani em Goiás.

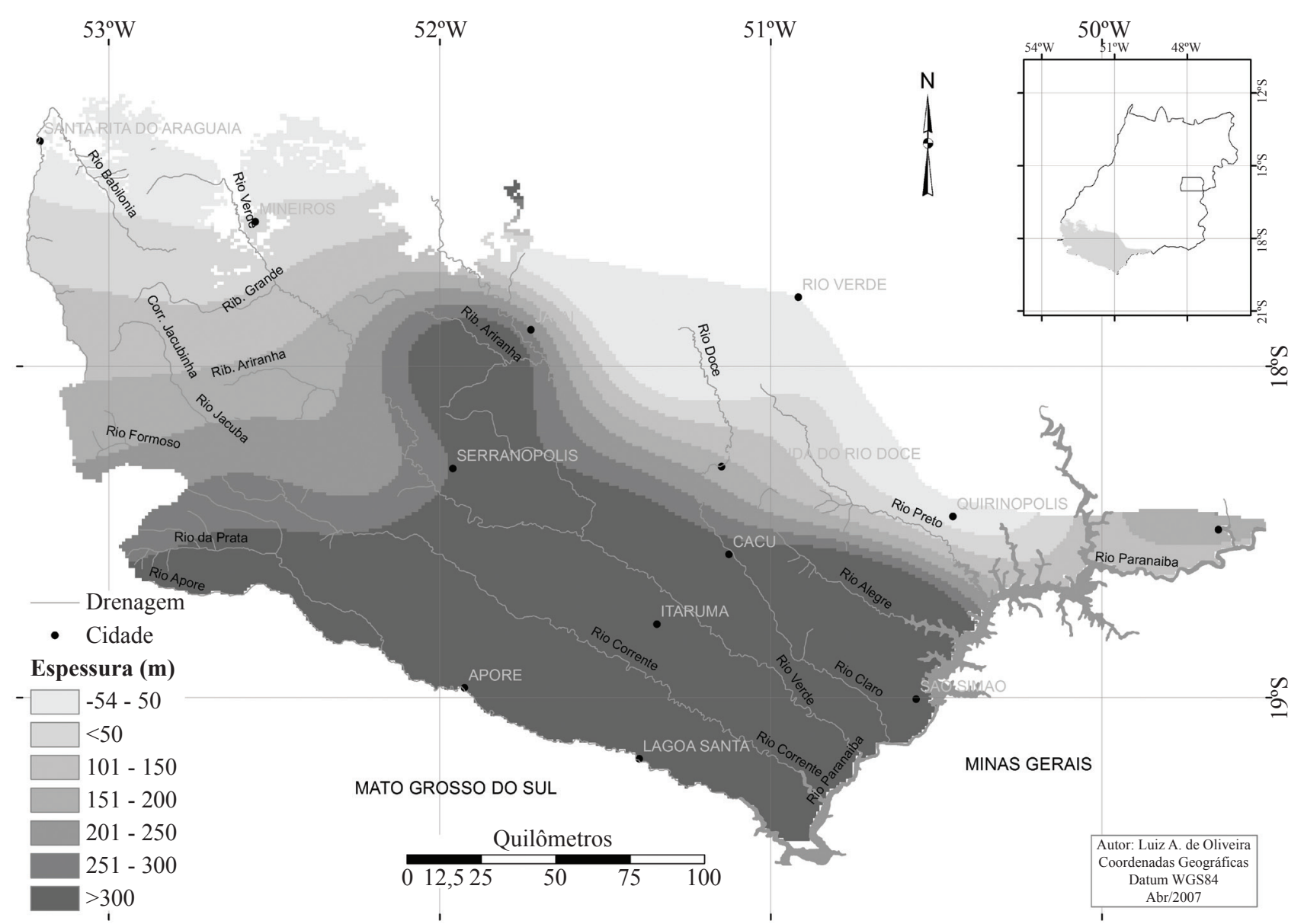

Figura 18 - Mapa de isópacas do Sistema Aquifero Guarani no estado de Goiás. 
das águas no SAG entre as porções posicionadas a leste e a oeste da estrutura (Oliveira 2009).

Ainda no Cretáceo, a subsidência térmica promoveu o rebaixamento do bloco posicionado a leste do lineamento do Rio Claro (NW-SE). Na porção oeste deste lineamento encontram-se a zona aflorante da região de Mineiros e uma zona de baixo grau de confinamento. Na porção leste do lineamento, há uma evolução do grau de confinamento em direção a DTRP. O gradiente topográfico, do topo do pacote arenítico, entre a zona aflorante e a porção confinada na DTRP é de mais de $1.800 \mathrm{~m}$. Na área de recarga de Mineiros, os valores máximos de cotas altimétricas dos arenitos aproximam-se de $900 \mathrm{~m}$. A partir da área de recarga, em direção a leste e a sudeste, segue-se a zona de baixo grau de confinamento do aquífero, onde na região de Lagoa Santa, posicionada no extremo sul do estado, divisa com Mato Grosso do Sul, a camada confinante de basaltos possui $140 \mathrm{~m}$ de espessura. $\mathrm{Na}$ Usina dos Coqueiros, situada entre Lagoa Santa e a zona aflorante de Serranópolis, a espessura dos basaltos é de $40 \mathrm{~m}$. Blocos falhados de basalto são encontrados no limite norte e no interior dos afloramentos da região de Mineiros. Na porção mais interior dessa região, recobrindo os arenitos, de forma localizada, encontram-se lentes delgadas de saprólitos de basalto, indicando que os derrames basálticos, apesar de pouco espessos, eram contínuos e recobriam toda a região.

No final do Cretáceo e início do Terciário, a reativação de planos de falhas de direção NW-SE, perpendiculares ao plano de falha principal relacionado à DTRP, permitiu a instalação dos lineamentos dos rios Aporé, Corrente, Verde e Claro. Outro evento tectônico de idade terciária novamente reativou os planos de falhas de direção NW-SE e promoveu o soerguimento do aquífero na área situada entre os rios citados. Os litotipos sobrepostos ao SAG: rochas do Grupo Bauru e basaltos da Formação Serra Geral foram erodidos e transportados para novos sítios deposicionais, dando origem aos sedimentos cenozóicos da Formação Cachoeirinha e as coberturas arenosas indiferenciadas. Atualmente, os afloramentos do aquífero nos municípios de Mineiros e Serranópolis, estão em contato lateral com os sedimentos cenozoicos, sendo as unidades separadas por linhas de falhas relacionadas aos rios Jacuba e Verde.
CONSIDERAÇÕES FINAIS A relação entre as cotas dos contatos geológicos, do aquífero na zona de recarga com as formações permianas sotopostas permite interpretar que nesta ampla área de exposição, grande parte da água de precipitação infiltrada é drenada pela rede hidrográfica. Esta conclusão é coerente com os dados levantados em campo e em perfis de poços existentes nas áreas de recarga de Mineiros (alto curso dos tributários do rio Paranaíba e em toda a bacia do rio Araguaia) e de Jataí (alto curso dos ribeirões Paraíso e das Torres). Esta observação mostra que a eficiência da recarga nas áreas de exposição é menor que o historicamente considerado. Assim, recomenda-se a realização do balanço hídrico nas áreas de recarga, de forma a se ampliar o entendimento da dinâmica de recarga do aquífero em sua zona aflorante.

Análise comparativa entre as informações do comportamento do aquífero no estado de Goiás, com aquelas descritas em outras regiões de ocorrência na América do Sul, permite destacar algumas particularidades no estado: a) as águas da região de Cachoeira Dourada, devido às altas concentrações de cloretos e de sulfatos, são as mais mineralizadas de toda a extensão do sistema aquífero; b) as cotas mais elevadas do aquífero, alcançando os $900 \mathrm{~m}$, encontram-se na zona aflorante de Jataí; c) as idades de circulação mais antigas até então relatadas, superiores a 40.000 anos, relacionam-se às regiões de Cachoeira Dourada e Quirinópolis.

Dentre o conjunto de conhecimentos produzidos pelo presente trabalho merecem destaques: o detalhamento da estrutura do aquífero, principalmente a definição da extensão nordeste do Lineamento do Rio Paraná, coincidente com o curso do rio Paranaíba, sendo a principal estrutura de controle regional do aquífero no estado; o entendimento da interação e da influência das águas de outros aquíferos com o Sistema Guarani; a redefinição dos limites do aquífero, com retração da área de ocorrência até então proposta, resultando em um novo mapa de distribuição;

AGRADECIMENTOS Os autores agradecem ao Conselho Nacional de Desenvolvimento Científico e Tecnológico (CNPq) pela concessão de financiamento ao projeto de pesquisa Processo $n^{\circ}$ 474453/2006-5, sem o qual não seria possível a realização desse trabalho. 


\section{Referências}

Almeida L. 2003. Caracterização hidrogeológica da bacia do alto Rio Claro no estado de Goiás: subsídios para o gerenciamento dos recursos hídricos. Dissertação (Mestrado em Geologia). Instituto de Geociências. Universidade de Brasília. 101 p.

AGÊNCIA NACIONAL DE ENERGIA ELÉTRICA (ANEEL). 2000. Sistema de Informações Georreferenciadas de Energia e Hidrologia (HIDROGEO), Versão 1.1. Bacia 6 - Bacia Sedimentar do Paraná. CD-ROM.

Araújo L.M, França A.B, Potter P.E. 1995. Aquífero gigante do Mercosul - Brasil, Argentina, Uruguai e Paraguai: mapas hidrogeológicos das Formações Botucatu, Pirambóia, Rosário do Sul, Buena Vista, Misiones e Tucuarembó. Curitiba, UFPR/PETROBRÁS.

Araújo L.M., França A.B., Potter P.E. 1999. Hydrogeology of the Mercosul Aquifer System in the Paraná and Chaco-Paraná Basins, South America, and comparison with the Navajo-Nugget Aquifer System, USA. Hidrogeology Journal, 7:317-336.

Azevedo S.A., Lavina E.L., Barberena M.C., Ferrando L., Andreis R.R. 1985. Evidências de correlação entre a Formação Yaguari (Membros Inferior e Superior) e as Formações Rio do Rasto e Sanga do Cabral. Revista Pesquisas, 17:112-121.

Campos H.C.N.S. 1996. Mapa hidrogeológico do Aquífero Guarani. ISOMAPA - Consultoria e Projetos Ltda. São Paulo, escala 1:2.500.000.

CONSÓRCIO GUARANI. 2006. Serviços de hidrogeologia geral, termalismo e modelo regional do Aquífero Guarani. Relatório interno, Montivideo, 197 p.

Decoud P. \& Rocha L. 2000. Aportes a la hidráulica subterránea del Acuífero Guarani en el NW del Uruguay. In: Joint World Congress on Groundwater, 1., 2000, Fortaleza. Anais... São Paulo: Associação Brasileira de Águas Subterrâneas. 1 CD.

França A.B., Milani E.J., Schneider R.L., Pausen O.L., Lopez J.M., Soruco R.S., Sant'Ana H., Wieus F., Ferreiro O., Rossel E.A., Bianucci H.A., Flores R.F.A., Vistali M.C., Sevesso F.F., Fuenzolida R.E., Muñoz N. 1994. Correlação fanerozóica na parte austral da América do Sul. PETROBRAS/NEXPAR/ YPBF, ANCAP. PETROPAR YPF SIPETROL.

Galhano F.A.P. 2006. Petróleo e gás na Bacia do Paraná. 108 f. Tese (Doutorado em Geociências) - Departamento de Engenharia de Minas e de Petróleo, Escola Politécnica da Universidade de São Paulo, São Paulo.

Gastmans D. 2007. Hidrogeologia e hidroquimica do Sistema Aquífero Guarani na porção ocidental da Bacia Sedimentar do Paraná. 194 f. Tese (Doutorado em Geociências) - Instituto de Geociências e Ciências Exatas, Universidade Estadual Paulista "Júlio de Mesquita Filho", Rio Claro.

Giardin A. \& Faccini U. 2004. Complexidade hidroestratigráfica e estrutural do Sistema Aquífero Guarani: abordagem metodológica aplicada ao exemplo da área de Santa Maria-RS, Brasil. Revista Águas Subterrâneas, 18:39-54.

Oliveira L.A. 2009. O Sistema Aquífero Guarani no estado de Goiás: distribuição, caracterização hidrodinâmica, hidroquímica, composição isotópica e CFCs. 188 p. Tese (Doutorado em Geologia)., Instituto de Geociências, Universidade de Brasília, Brasília.

Palmieri J., Fulfaro V., Alvarenga J. 1990. República del Paraguay. Gobierno de la República del Paraguay, Comisión Nacional de Desarrollo Regional Integrado del Chaco Paraguayo y Departamento de Cooperación Técnica para el Desarrollo de la Organización de las Naciones Unidas. Asunción/Py. Mapa geológico, escala 1:1.000.000.

Rosa Filho E.F. 2003. Fatores controladores da hidrodinâmica do Sistema Aquífero Guarani no estado do Paraná. Curitiba: Universidade Federal do Paraná. 49 p.

Rosa Filho E.F. 2004. Fatores controladores da hidrodinâmica do Sistema Aquífero Guarani no estado do Paraná. Curitiba: Universidade Federal do Paraná. 49 p.

Santa Ana H.B.A. 2004. Análise tectono-estratigráfica das seqüências permotriassica e jurocretácea da bacia chacoparanense uruguaia ("cuenca norte"). $274 \mathrm{f}$. Tese (Doutorado em Geologia) -. Instituto de Geociências e Ciências Exatas, Universidade Estadual Paulista "Júlio de Mesquita Filho", Rio Claro.

Zunino E. \& Ainchil J. 2000. Evaluación geofísica del Acuífero Guarani en la Argentina. In: JOINT WORLD CONGRESS ON GROUNDWATER, 1, Fortaleza. Anais... São Paulo: Associação Brasileira de Águas Subterrâneas. 1 CD.

Manuscrito ID 24942

Recebido em: 07/11/2011 Aprovado em: 11/10/2012 